\title{
Analisis Keberhasilan Inseminasi Buatan (IB) Ternak Sapi Berdasarkan Karakteristik Inseminator di Kabupaten Kerinci
}

\author{
Lusi Amidia*, Fachroerrozi Hoesni, Bayu Rosadi \\ Magister Ilmu PeternakanProgram Pascasarjana Universitas Jambi \\ *Correspondence email: lusiamidia23@gmail.com
}

\begin{abstract}
Abstrak. Penelitian ini bertujuan untuk mengetahui pengaruh karakterisitik internal dan eksternal inseminator terhadap keberhasilan IB di Kabupaten Kerinci. Penelitian ini dilaksanakan pada tanggal 12 Desember 2020 sampai dengan tanggal 6 Januari 2021. Objek yang diamati pada penelitian ini adalah seluruh inseminator yang ada pada setiap pos IB di Kabupaten Kerinci. Data yang diperoleh dari penelitian ini adalah data primer dan data sekunder. Data yang dianalisis menggunakan analisis Regresi Berganda Stepwise. Hasil analisis menunjukkan bahwa keberhasilan inseminasi buatan di Kabupaten Kerinci sudah baik, hal ini dapat dilihat dari nilai S/C per inseminator sebesar 1,69. Pengaruh karakteristik internal (masa kerja, intensitas pelatihan, ketelitian, kemampuan teknis manajemen straw dan deteksi birahi) dan eksternal (jarak rumah dengan wilayah kerja, fasilitas pendukung, kondisi pos IB, sanitasi alat dan kelengkapan) berpengaruh ( $\mathrm{P}>0.05)$, sedangkan karateristik internal (tanggung jawab) dan eksternal (imbalan sukarela) tidak berpengaruh $(\mathrm{P}>0.05)$ terhadap keberhasilan IB di Kabupaten Kerinci. Berdasarkan penelitian ini dapat disimpulkan bahwa tidak semua karakteristik internal dan karakteristik eksternal mempengaruhi keberhasilan IB di Kabupaten Kerinci.
\end{abstract}

Kata kunci: IB; Inseminator; Karakteristik Internal dan Eksternal.

Abstract. This study aims to determine the effect of internal and external inseminator characteristics on the success of IB in Kerinci Regency. This research was conducted on December 12, 2020 to January 6, 2021. The objects observed in this study were all inseminators at each IB post in Kerinci Regency. The data obtained from this study are primary data and secondary data. The data were analyzed using Stepwise Multiple Regression analysis. The results of the analysis show that the success of artificial insemination in Kerinci Regency is good, this can be seen from the S/C value per inseminator of 1.69.The influence of internal characteristics (length of work, training intensity, accuracy, technical ability of straw management and estrus detection) and external (distance from house to work area, supporting facilities, condition of post IB, sanitation of tools and fittings) has an effect $(P>0.05)$. Meanwhile, internal characteristics (responsibility) and external (voluntary rewards) have no effect (P>0.05) on the success of IB in Kerinci Regency. Based on this research, it can be concluded that not all internal and external characteristics affect the success of IB in Kerinci Regency.

Keywords : Artificial Insemination (AI); Inseminator; Internal and Eksternal Characteristics.

\section{PENDAHULUAN}

Subsektor peternakan berperan penting dalam mencukupi kebutuhan pangan yang berasal dari ternak, terutama daging. Daging sapi merupakan salah satuproduk hasil ternak dengan peminat yang paling tinggi dan memiliki kontribusi terbesar kedua sebesar 15.45 persen terhadap konsumsi daging nasional setelah daging ayam yang diperkirakan akan terus mengalamipeningkatantiap tahunnya (Kementan, 2017).

Keadaan ini berbanding terbalik dengan produksi daging dalam negeri yang belum optimal,masih bergantung pada impor. Berbagai upaya yang dilakukan pemerintah untuk peningkatan produktivitas dan populasi ternak. Pada tahun 2020 Direktorat Jenderal Peternakan dan Kesehatan Hewan (PKH) mencanangkanprogram baru yakni SIKOMANDAN (Sapi dan Kerbau Komoditas Andalan Negeri). Program ini bertujuan untuk meningkatkan populasi dan produksi ternak sapi dan kerbau, serta menekan angka dominasi impor sapi indonesia melalui optimalisasi reproduksi ternak yang dalam pelaksanaannya salah satunya dilakukan melalui perkawinan buatan (IB).
Perkawinan ternak melalui IB diharapkandapat membantupeternak untuk meningkatkan kualitas mutu genetik ternak, sehingga adanya keseimbangan tingkat pemotongan yang pada akhimya dapat mempertahankan jumlah populasi, dan menekan penyebaran penyakitpenyakit tertentu pada ternak sapi (Setiawan, 2018).

Keberhasilan pelaksanaanIB di Kabupaten Kerinci tidak lepas dari faktor kecakapan petugas inseminator yang sangat berperan sebagai pihakpenentu berhasil atau tidaknya penerapan IB di lapangan. Hal ini didukung pendapat Utami dan Angris (2012) menyatakan bahwakeberhasilan IB tidak lepas dari berbagai aspek yang saling berhubungan erat, meliputi keterampilan inseminator dalam mendeteksi birahi, sanitasi alat, penanganan semen beku, proses (thawing), serta kemampuanmelakukan IB.

Upaya untuk melihat kinerja reproduksi hasil IB, diperlukan suatu penelitian mengenai faktor yang mempengaruhi keberhasilan IB berdasarkan karakteristik internal (masa kerja, intensitas pelatihan, tanggung jawab, ketelitian, kemampuan teknis manajemen straw dan deteksi birahi) dan eksternal (jarak rumah dengan 
wilayah kerja, fasilitas pendukung, kondisi pos IB, sanitasi alat dan kelengkapan, imbalan sukarela) inseminator untuk menyukseskan keberhasilan kebuntingan ternak sapi di Kabupaten Kerinci.

\section{METODE}

Metode penelitian yang digunakan pada penelitian ini adalah metode sensus, dimana respondennya adalah seluruh inseminator yang ada pada setiap pos IB di Kabupaten Kerinci. Ternak yang dijadikan sampel adalah 93 ekor akseptor IB dari 59 peternak. Adapun tenik pengambilan sampel dilakukan secara acak (Simple Random Sampling).

Uji validitas instrument dalam penelitian ini dengan mengkorelasikan skor masing-masing pertanyaan dengan skor total pertanyaan untuk setiap variabel, secara umum perumusan nilai korelasi person (product moment person) adalah :

$r=\frac{n \sum X Y-\left(\sum X\right)\left(\sum Y\right)}{\sqrt{\left\{n \sum X^{2}-\left(\sum X\right)^{2}\right\}\left[n \sum Y^{2}-\left(\sum Y\right)^{2}\right\}}}$

Keterangan:

$\mathrm{R}=$ Korelasi Person

$\mathrm{Y}=$ Skor total pertanyaan

$\mathrm{N}=$ Jumlah Pertanyaan

$\mathrm{X}=$ Skor Pertanyaan

Selanjutnya untuk signifikannya di uji dengan formula sebagi berikut :

$t_{\text {hitung }}=\frac{r \sqrt{n-2}}{\sqrt{1-r^{2}}}$ pada $\mathrm{db}=\mathrm{n}-2$

Uji reliabilitas untuk mengetahui tingkat keterpercayaan, keterandalan, konsistensi, atau kestabilan hasil suatu pengukuran. Alat ukur dapat dikatakan reliabel, apabila dilakukan pengukuran secara berkali-kali akan menunjukkan hasil yang sama dan tidak mengalami perubahan dalam mengungkapkan gejala tertentu dari sekelompok individu, walaupun dilakukan pada yang berbeda.Uji reabilitas instrument pada pada pelaksanaannya mengunakan metode belah dua (split half method)

Skala pengukuran dari data yang diperoleh bervariasi yaitu skla ordinal dan rasio.Data ordinal dilakukan transformasi menjadi skala interval dengan menggunakan Methods of Successive Interval (MSI). Selanjutnya untuk mengetahui faktor karakteristik internalapa saja yang mempengaruhi keberhasilan IB digunakan analisis Regresi Berganda StepWise dengan model persamaan sebagai berikut:

$Y=\alpha+\beta_{1} X_{1}+\beta_{2} X_{2}+\beta_{3} X_{3}+\beta_{4} X_{4}+\beta_{5} X_{5}+\varepsilon$

Dimana :

Y : Keberhasilan IB

$\mathrm{X}_{1}$ : Masa kerja
$\mathrm{X}_{2} \quad$ : Intensitas Pelatihan

$\mathrm{X}_{3}$ : Tanggung jawab

$\mathrm{X}_{4} \quad$ : Ketelitian

$\mathrm{X}_{5}$ : Kemampuanteknis dalam manajemen straw dan mendeteksi birahi

$\alpha \quad$ : Konstanta

$\beta \beta_{1-5}$ : Koefisien variabel $X_{1}-X_{5}$

$\varepsilon \quad$ : Residual atau variabel pengganggu (error term).

Untuk mengetahui faktor karakteristik eksternal apa saja yang mempengaruhi keberhasilan IB digunakan analisis Regresi Berganda StepWise dengan model persamaan sebagai berikut:

$Y=\alpha+\beta_{1} X_{1}+\beta_{2} X_{2}+\beta_{3} X_{3}+\beta_{4} X_{4}+\beta_{5} X_{5}+\varepsilon$

Dimana :

Y : Keberhasilan IB

$\mathrm{X}_{1}$ : Jarak rumah inseminator ke wilayahkerja

$\mathrm{X}_{2}$ : Fasilitas pendukung

$\mathrm{X}_{3} \quad$ : Kondisi pos IB

$\mathrm{X}_{4}$ : Sanitasi alat dan kelengkapan

$\mathrm{X}_{5} \quad$ : Imbalan Sukarela

$\alpha \quad$ : Konstanta

$\beta \beta_{1-5}$ : Koefisien variabel $X_{1}-X_{5}$

$\varepsilon \quad$ : Residual atau variabel pengganggu (error term)

\section{HASIL DAN PEMBAHASAN}

Keberhasilan Inseminasi Buatan

Hasil evaluasi keberhasilan pelaksanaan IB di Kabupaten Kerinci, dapat di diukur dengan cara menghitungangka kawin per kebuntingan atau Service per Conception (S/C) yang merupakan jumlah pelayanan inseminasi (service) yang dibutuhkan oleh ternak induk, hingga diperoleh kebuntingan.

Adapun hasil S/C di kabupaten Kerinci tertera pada Tabel 1.

Tabel 1. Data Service per Conception Inseminator di Kabupaten Kerinci

\begin{tabular}{clc}
\hline No & \multicolumn{1}{c}{ Inseminator } & S/C \\
\hline 1 & Terendah & $1.27 \pm 0.47$ \\
2 & Tertinggi & $2.50 \pm 0.71$ \\
& Rata-rata & $\mathbf{1 . 6 9} \pm \mathbf{0 . 3 2}$ \\
\hline
\end{tabular}

Sumber data : data diolah (2020)

Hasil penelitian pada Tabel 1.menunjukkan bahwa rata-rata angka S/Csetiap petugas inseminator memiliki hasil capaian angka S/C terendah atau dengan kisaran angka S/C sebesar $1.27 \pm 0.47$, sedangkan angka S/C tertinggi sebesar $2.50 \pm 0.71$.Secara keseluruhan hasil capaian angka S/C rata-rata sebesar $1.69 \pm 0.32$, yang menandakan kesuburan yang cukup tinggi. Hal ini didukung pendapat Feradis (2010) bahwa S/C yang baik adalah 1.6 sampai 2.0 kali. Nilai S/C menunjukkan kesuburan pada ternak.Semakin tinggi nilai S/C semakin rendah tingkat kesuburannya, sebaliknya jika semakin rendah nilai $\mathrm{S} / \mathrm{C}$ menandakan tingkat kesuburan pada 
ternak semakin tinggi.Nilai S/C di Kabupaten Kerinci pada penelitian ini lebih baik dari diperoleh hasilpenelitian Saputra et al. (2019) pada sapi Bali di Kecamatan Sentajo Raya Kabupaten Kuantan Singingi S/C sebesar1.75. Penyebab tingginya angka S/C (Service per Conception) umumnya dikarenakanketerlambatan dalam mendeteksi birahi,sehingga pelaksanaan IB mundur dari waktu birahi, adanya kelainan pada alat reproduksi ternak akseptor, inseminator kurang terampil, fasilitas pelayanan inseminasi masih terbatas, serta kurang lancarnya transportasi menuju lokasi peternak (Hadi dan Ilham, 2002).

\section{Karakteristik Inseminator}

Karakteistik internal yang diamati dalam penelitian ini meliputi masa kerja inseminator, intensitas pelatihan, tanggung jawab, ketelitian, kemampuan teknis manajemen straw. Adapun karakteristik Inseminator di Kabupaten Kerinci dapat dilihat pada Tabel 2. berikut ini.

Tabel 2. Karakteristik Internal Inseminator di Kabupaten Kerinci

\begin{tabular}{|c|c|c|c|c|}
\hline No & Kategori & & Karakter Responden & \% Responden \\
\hline \multirow{5}{*}{1} & \multirow{5}{*}{ Masa Kerja } & & $<5$ & 7.14 \\
\hline & & & $5-10$ & 50 \\
\hline & & & $11-15$ & 21.43 \\
\hline & & & $16-20$ & 7.14 \\
\hline & & & $>20$ & 14.29 \\
\hline \multirow{4}{*}{2} & \multirow{4}{*}{ Intensitas Pelatihan } & & 1 & 35.71 \\
\hline & & & 2 & 28.57 \\
\hline & & & 3 & 14.29 \\
\hline & & & 4 & 21.43 \\
\hline \multirow{5}{*}{3} & \multirow{5}{*}{ Tanggung Jawab } & $\square$ & Sangat Tidak Bersedia & 0.00 \\
\hline & & $\square$ & Tidak Bersedia & 3.06 \\
\hline & & $\overline{0}$ & Ragu-Ragu & 19.39 \\
\hline & & $\overline{0}$ & Bersedia & 51.02 \\
\hline & & $\square$ & Sangat Bersedia & 26.53 \\
\hline \multirow{5}{*}{4} & \multirow{5}{*}{ Ketelitian } & $\square$ & Sangat Tidak Setuju & 0.00 \\
\hline & & 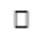 & Tidak Setuju & 0.00 \\
\hline & & $\square$ & Ragu-Ragu & 22.86 \\
\hline & & ( & Setuju & 55.72 \\
\hline & & $\bar{\square}$ & Sangat Setuju & 21.43 \\
\hline \multirow{5}{*}{5} & \multirow{5}{*}{$\begin{array}{l}\text { Kemampuan Teknis } \\
\text { Manajemen Straw } \\
\text { dan Deteksi Birahi }\end{array}$} & $\square$ & Sangat Tidak Setuju & 1.43 \\
\hline & & $\square$ & Tidak Setuju & 5.00 \\
\hline & & 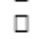 & Ragu-Ragu & 15.72 \\
\hline & & $\square$ & Setuju & 43.57 \\
\hline & & $\square$ & Sangat Setuju & 34.29 \\
\hline
\end{tabular}

Sumber data: data diolah (2020)

\section{Masa Kerja}

Pengalaman inseminator yang luas membutuhkan masa kerja yang cukup lama, bertambahnya pengalaman kerja inseminator akan semakin meningkatkan kualitas kinerja (Kotur dan Anbazhagan, 2014).

Berdasarkan Tabel 2. menunjukkan bahwa ratarata masa kerja sebagian besar inseminator di Kabupaten Kerinci berkisar $5-10$ tahun $(50 \%)$, masa kerja minimum inseminator adalah $<5$ tahun $(7,14 \%)$, sedangkan masa kerja maksimum inseminator adalah > 20 tahun $(14,29 \%)$ masih sedikit. Masa kerja inseminator dapat mempengaruhi kualitas kinerja inseminator di lapangan. Inseminator yang masih baru memilikipengalaman yang berbeda dengan inseminator yang sudah memiliki masa kerja cukup lama karena berpengaruh pada kecakapan (pengetahuan) kerja yang bertambah baik, serta meningkatnya keterampilan ke arah yang lebih baik dalam segi kualitas maupun kuantitas.

\section{Intensitas Pelatihan}

Pelatihan merupakan program yang sangat penting diikuti bagi setiap inseminator yang bertujuan untuk mengembangkan keterampilan dan keahlian inseminator, sehingga dapat membantu meningkatkan efektivitas dan produktivitas dalam kelancaran

Berdasarkan Tabel 2. menunjukkan bahwa ratarata inseminator di Kabupaten Kerinci telah mengikuti frekuensi pelatihan sebanyak 1 kali dengan persentase 5 orang (35.71\%), sedangkan frekuensi pelatihan 4 kali masih sedikit diikuti inseminator dengan presentase 3 orang (21.43\%). Menurut Bosker (1997) menyatakan bahwa pelatihan merupakan suatu kegiatan pembelajaran yang terprogram dengan tujuan untuk meningkatkan kemampuan dan keterampilan seseorang dalam kinerjanya.

\section{Tanggung Jawab}

Dari hasil yang diperoleh pada Tabel 2. Bahwa inseminator di Kabupaten Kerinci memiliki rasa tanggung jawab cukup baik dengan rata-rata tertinggi sebanyak (51.02\%) dan terendah (3.06\%). Hal ini menjelaskan bahwa inseminator di Kabupaten Kerinci telah melaksanakan tugas, wewenang, dan kewajiban secara profesional yang dalam proses menginseminasi ternak sapi sudah dilakukan dengan tepat dan benar. Diperkuat pendapat Siagian (2009) bahwa profesionalisme adalah keahlian seseorang dalam menyelesaikan suatu tugas sehingga tercapainya hasil yang bermutu tinggidengan waktu yang tepat dan akurat.Dalam upaya peningkatan mutu profesionalitas sebagian besar inseminator belum menekuni profesinya secara utuh karena belum banyak mengikuti pelatihan.

Inseminator sangat menerapkan prinsip hatihatisaat menginseminasi ternak bertujuan untuk meminimalisir terjadinya kegagalan IB/terjadi kecelakaan di lapangan.Keadaan di lapangan menjelaskan bahwa sebagian inseminator yang masih berusia muda masih belum berani mengambil resiko dilapangan, mengambil resiko berarti inseminator harus bersedia menghadapi tantangan dan hal-hal yang tidak bisa diprediksi di lapangan dan tetap harus berani mengambil resiko atas setiap keputusan yang diambil, serta tidak boleh mengelak bila diminta penjelasan tentang perbuatannya. Keadaan di lapangan belum pernah ditemukan kesalahan saat menginseminasi ternak sapi karena inseminator telah terlatih. Bagi petugas inseminator dengan kinerja baru, biasanya sering bertukar pengalaman dengan inseminator yang masa kerja lama untuk mendapatkan tambahan ilmu, sehingga dapat meminimalisir kendala saat pelaksanaan IB. Kerja 
sama antar inseminator sangat diperlukan karena berpengaruh terhadap

kualitas dan prestasi dalam menyelesaikan pekerjaan. Hal ini didukung pendapat Setiyanti (2012) menyatakan bahwa kerja sama akan bertujuan untuk memudahkan pembinaan hubungan kerja, sehingga dapat menunjang dan mempercepat peningkatan produktivitas kerja.

Ketika peternak menghubungi untuk menginseminasi ternak sapinya petugas inseminator selalu cepat tanggap dalam memberi pelayanan IB seperti di hari libur inseminator tetap meluangkan waktu untuk datang menginseminasi ternak sapi, apabila berada di luar daerah biasanya inseminator bersedia untuk mengantikan dengan petugas lain yang berada pada wilayah kerja yang sama. Pergantian ini tentu atas persetujuan peternak karena di Kabupaten Kerinci peternak masih menganut paham fanatisme cukup tinggi yang hanya percaya pada satu petugas yang sama untuk menginseminasi ternaknya.

\section{Ketelitian}

Tercapainya keberhasilan IB tentu dibutuhkan tenaga inseminator yang mempunyai pribadi yang teliti, dengan sikap berpikir dahulu sebelum bertindak, mengikuti peraturan dan norma, sehingga dapat dikatakan kepribadian teliti sangat diperlukan karena kepribadian ini adalah dasar pembentukan perilaku kerja yang tinggi dengan tujuan jangka panjang dalam mengarahkan perilaku tujuan yang biasanya ada pada orang lain.

Temuan hasil penelitian ini tentang ketelitian inseminator di Kabupaten Kerincidiperolehrata-rata persentase tertinggi sebesar $(55.72 \%)$ dan terendah $(21.43 \%)$. Hal ini menjelaskan bahwa pada saat pelayanan IB,petugas inseminator biasanya datang ketempat akseptor setelah peternak memberi tahu birahi pada ternaknya, apabila waktu pelaksanaan IB tidak tepat maka tidak akan terjadi kebuntingan pada ternak. Hal ini sesuai pendapat Saacke (2008) dan Roelofs et al.(2010) keberhasilan IB melibatkan hubungan yang kompleks antara deteksi estrus, ketepatan waktu IB, kemampuan inseminator peternak, serta kualitas semen dan oosit.

Inseminator menggunakan alat IB sesuai prosedur dan melakukan pemeriksaan pada ternak yang dijadikan akseptor sebelum di IB, namun inseminator tidak melakukan pemeriksaan ternak setelah diinseminasi. Pemeriksaan sebelum dan sesudah IB penting dilakukan seperti memastikan kualitas semen yang akan digunakan berkualitas baik serta, pengecekan alat reproduksi betina juga penting dilakukan dan harus yakin bahwa sapi yang akan diinseminasi tidak dalam keadaan bunting, karena sapi bunting juga sering menunjukkan gejalagejala berahi (meskipun palsu). Hal ini sesuai penelitian Elvica (2018) menyatakan bahwa apabila tidak dilakukan pemeriksaan kesehatan ternak sebelum dan sesudah IB akan membuat kegagalan IB semakin meningkat. Disamping itu inseminatorperlu jugamengecek kelayakan alat IB yang akan digunakan sebelum menginseminasi ternak.

Setiap pelaksanaan IB, inseminator membuat laporan hasil IB secara rinci.Pembuatan laporan bertujuan untuk mengetahui jumlah sapi straw yang digunakan, tanggal pelaksanaan IB dan jumlah kebuntingan akseptor.Sebagian besar petugas inseminator telah membuat laporan secara rinci seperti tanggal pelaksanaan IB, umur, kesehatan, status, dan silsilah masing-masing akseptor ternak sesuai wilayah kerjanya dan melaporkan ke ISIKHNAS.ISIKHNAS merupakan layanan sistem informasi kesehatan hewan Indonesia berbasis teknologi cerdas, yang dapat diakses dimanapun dan kapanpun, yang memberi kemudahan bagi setiap inseminator mengambil data di lapangan dengan cepat sedekat mungkin dari sumbernya.

\section{Kemampuan Teknis Manajemen Straw dan Deteksi Birahi}

Temuan dari penelitian ini tentang kemampuan teknis manajemen straw dan deteksi birahi oleh inseminator dengan rata-rata tertinggi sebesar $(43.57 \%)$ dan terendah (1.43\%).Hal ini menunjukkan bahwa penanganan semen beku dalam kontainer sudah dilakukan dengan baik. Kontainer yang sering dibuka menyebabkan terjadinya penguapan N2 cair lebih tinggi, serta adanya pengaruh sinar, debu, sabun, air dan darah secara langsung akan menurunkan kualitas semen. Proses penyimpanan semen dipastikan straw dalam posisi terendam N2 cair dan setiap goblet penuh dengan $\mathrm{N} 2$ cair yang jaraknya minimal $>15 \mathrm{~cm}$ dari dasar kontener.

Pengambilan straw tidak boleh melebihi tinggi leher kontainer karena dapat menyebabkan terjadi perubahan suhu yang berdampak pada kualitas semen. Hal ini didukung pendapat Yatim (1982) bahwa temperatur terlalu tinggi atau terlalu rendah akan merusak pertumbuhan dan kemampuan spermatozoa untuk membuahi. Semen beku yang digunakan untuk IB sudah diencerkan dengan ketentuan prosedur produksi sehingga menjadi semen beku yang disimpan didalam rendaman nitrogen cair pada suhu $196{ }^{\circ} \mathrm{C}$ dalam Kontainer kriogenik (SNI, 2008).

Staw beku yang setelah dithawing tidak perlu dikembalikan kedalam kontener lagi karena dapat memyebabkan turunnya kualitas semen, bahkan dapat menyebabkan kematian sperma. Hal ini didukung pendapat Toelihere (1993) menyatakan bahwa sesudah pencairan kembali, semen beku tidak dapat tahan lama seperti semen cair, sebaiknya semen digunakan segera setelah thawing untuk memperoleh efisiens reproduksi yang maksimal (Morrow, 1980).

Petugas inseminator merendam straw menggunakan air sumur dan jarang sekali menggunakan air hangat.Proses merendam straw berisi semen beku 
sebaiknya menggunakan air hangat suhu $37,5^{\circ} \mathrm{C}$ dalam waktu 25-30 detik. Hal ini diperkuat Utami dan Tophianong (2014) bahwa semen beku setelah thawing dalam air $37{ }^{\circ} \mathrm{C}$ memiliki kecenderungan menghasilkan motilitas yang lebih tinggi jika dibandingkan dengan dalam air $8{ }^{\circ} \mathrm{C}$ dan dianjurkan dengan cara suhu air ditingkatkan secara perlahan agar mengurangi tingkat kematian sel sperma (Susilawati, 2011).

Sebagian inseminator tidak setuju melakukan thawing menggunakan air es karena dapat menurunkan motilitas sperma. Hal ini dipertegas Al-Badry (2012) dalam penelitiannya melaporkan, bahwa thawing semen beku di dalam air $5^{\circ} \mathrm{C}$ menunjukkan hasil yang berbeda signifikan terhadap thawingdidalam air bersuhu $37^{\circ} \mathrm{C}$ dan $60^{\circ}$ C. Selanjutnya ditambahkan Watson (1996) menyatakan bahwa prosesthawing dengan suhu rendah akan mengakibatkan struktur fosfolipid membrane plasma akan berubah dari fase cair menjadi fase gel sehingga akan menyebabkan motilitas sperma yang rendah.

Tanda-tanda birahi sangat berperan penting terhadap kinerja reproduksi dari seekor ternak yang akan di IB. Tingkat pemahaman inseminator mengenai gejala birahi pada ternak sudah baik karena petugas sudah melakukan pelatihan dan memiliki pengetahuan yang luas mengenai cara mendeteksi birahi. Deteksi birahi adalah prasyarat untuk IB, membantu prediksi waktu ovulasi dan saat tepat IB dan meningkatkan angka konsepsi (Chaikhun et al., 2010). Kegagalan dalam deteksi birahi dapat menyebabkan kegagalan kebuntingan yang berdampak menurunnya efisiensi reproduksi sehingga mempengaruhi kebijakan ekonomi dalam pemeliharaan ternak (Siregar, 2011).

Hasil wawancara diperoleh inseminator yang setuju waktu ideal pelaksanaan IB adalah berkisar 9-12 jam setelah awal terlihat birahi. Inseminator biasanya melakukan IB pada sore hari, apabila ternaknya menunjukkan gejala birahi pada pagi hari. Sebaliknya jika terjadi birahi pada malam hari, pelaksanaan nya akan dilakukan pagi hari. Pelaksanaan IB sebaiknya tidak dilakukan pada siang hari karena spermatozoa rentan terhadap panas sinar matahari yang menurunkan keberhasilan IB (Susilawati, 2011).

Selanjutnya ditambahkan Abidin et al.(2012) bahwa ketepatan waktu dalam pelaksanaan IB dapat meningkatkan efektivitas serta efisiensi pelaksanaan Inseminasi Buatan. Setelah 21 hari dari IB, dilakukan pengamatan.Jika tidak terdapat gejala birahi pada induk selama dua siklus, kemungkinan sapi induk tersebut bunting.Inseminator dapat mengetahui kebuntingan ternak padawaktu insemination gun dimasukkan kedalam cervix yang terasa lengket, karena cervix akan tertutup lender tebal seperti karet yang menyerupai sumbat (Tappa et al., 2012).

Pemeriksaan kebuntingan dilakukan inseminator dengan metode palpasi rektal. Palpasi rektal merupakan pemeriksaan kebuntingan dengan cara sederhana, metode ini membutuhkan keterampilan dari inseminator yang telah mengikuti pelatihan PKB. Selain itu metode ini mampu mendiagnosa kebuntingan seekor ternak, sekaligus mengetahui posisi fetus dan memprediksikan kelahiran. Kebuntingan pada ternak biasanya terjadi pembesaran uterus seperti balon karet $(10-16 \mathrm{~cm})$ dan setelah hari ke 90 sebesar anak tikus (Boothby and Fahey, 1995).

\section{Karakteristik Eksternal}

Hasil penelitian karakteristik eksternal inseminator di Kabupaten Kerinci yang meliputi jarak rumah inseminator dengan wilayah kerja, fasilitas pendukung, kondisi pos IB, sanitasi alat dan kelengkapan, serta imbalan sukarela disajikan pada Tabel 3 berikut ini.

Tabel 3. Karakteristik Eksternal Inseminator di Kabupaten Kerinci

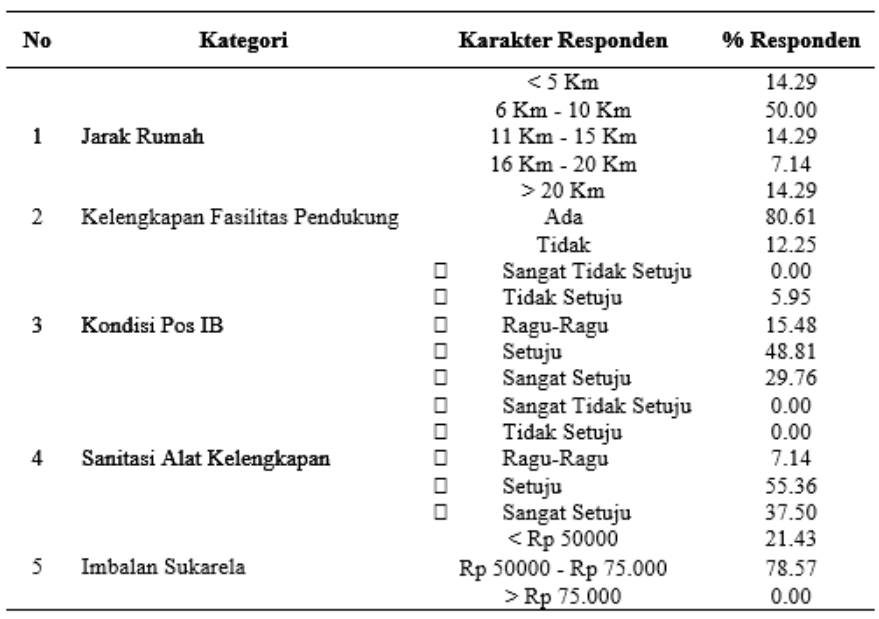

Sumber data: data diolah (2020)

\section{Jarak Rumah}

Jarak tempat tinggal menunjukkan berapa lama perjalanan yang ditempuh inseminator menuju tempat akseptor. Berdasarkan Tabel 3. Menunjukkan bahwa jarak rumah inseminator dengan wilayah kerja paling dekat $<5 \mathrm{~km}(14.29 \%)$, jarak rata-rata $6 \mathrm{Km}-10 \mathrm{Km}$ $(50.00 \%)$, sedangkan jarak paling jauh $>20 \mathrm{~km}$ $(14.29 \%)$.

Pada kondisi jarak tempuh yang jauh, inseminator memiliki banyak kendala dalam memberi pelayanan IB karena terdapat banyak wilayah yang mempunyai medan yang naik turun atau medan yang berat ditambah kondisi jalan yang rusak, apalagi musim hujan sangat menghambat kegiatan inseminasi.Menurut Wahyutae et al (2014) jarak tempuh inseminator ke wilayah kerja sangat berpengaruh terhadap kualitas semen, hal ini berdampak pada terjadi kegagalan IB. Selain itu juga berdampak pada kualitas semen. Perjalanan yang jauh dengan kondisi yang buruk seperti cuaca yang panas yang tinggi akan menurunkan kualitas semen (Toelihere, 1985). 


\section{Fasilitas Pendukung}

Fasilitas pendukung merupakan sarana yang sangat penting dimiliki oleh inseminator karena fasilitas tersebut dapat menunjang proses pelaksanaan IB. Temuan hasil peneitian pada Tabel 3. menunjukkan bahwa sebagian besar inseminator di Kabupaten Kerinci telah menggunakan fasilitas pendukung yang lengkap dengan persentase rata-rata paling tinggi $(80.61 \%)$ dan terendah (12.25\%). Fasilitas pendukung sangat berpengaruh pada kelancaran proses IB, karena saling berhubungan erat. Semakin lengkap fasilitas pendukung, maka akan memiliki peluang besar untuk tercapainya keberhasilan IB.

\section{Kondisi Pos IB}

Upaya mendukung program intensifikasi IB di Kabupaten Kerinci oleh pemerintah telah dibangun pos IB dengan masing-masing pos IB memiliki wilayah satu atau lebih kecamatan. Ruangan yang digunakan sebagai pos IB sudah bersih dan tertata rapi karena berada pada rumah inseminator yang memudahkan pembersihan. Sedangkan kondisi pos IB yang berada di kantor, kebersihan kurang terjaga. Setiap Pos IB memiliki ruangan penyimpangan kontener, dan memiliki kandang jepit, namun kondisi di lapangan menjelaskan bahwa inseminator biasanya membuat secara langsung kandang jepit di kandang peternak. Tujuan pembuatan kandang jepit untuk membatasi ruang gerak ternak sapi saat pelaksanaan IB, serta bagi peternak dimanfaatkan untuk memudahkan peternak melakukan perawatan kesehatan (potong kuku), dan penimbangan.

\section{Sanitasi Alat dan Kelengkapan}

Sanitasi merupakan sebuah program bertujuan untuk mencegah masuk dan perpindahan bibit penyakit yang menyerang ternak akibat kurang terjaganya kebersihan. Sanitasi alat dan kelengkapan IB perlu diterapkan karena sangat mempengaruhi terhadap keberhasilan IB.

Sebelum pelaksanaan IB, petugas inseminator melakukan sanitasi alat dan kelengkapan dengan diperoleh hasil rata-rata persentase tertinggi sebesar (55.36\%) dan terendah (7.14\%). Keadaan di lapangan menjelaskan bahwa sebelum melakukan IB pada ternak, biasanya inseminator terlebih dahulu membersihkan gunting dan pinset mengunakan alkohol agar steril. Penggunaan tisu/lap kain untuk membersihkan straw dan vulva yang kotor. Adapun proses mengeringkan termos lapangan dengan cara diangin-anginkan dan inseminasi gun lengkap dengan selubung-selubungnya dalam keadaan steril ketika digunakan.

\section{Imbalan Sukarela}

Inseminator tidak pernah meminta biaya lebih kepada peternak dalam memberi pelayanan IB. Imbalan sukarela di berikan oleh peternak kepada inseminator sebagai rasa ucapan terimakasih karena inseminator tetap bersedia memberi pelayanan IB, walaupun jarak yang jauh. Berdasarkan Tabel 3. diketahui bahwa inseminator mendapat imbalan sukarela dari peternak sebagian besar Rp. 50.000 - Rp 75.000 (78.57\%) dan ada juga yang mendapatkan < Rp. 50.000 (21.43\%). Pada pelaksanaan IB, masih ada petugas inseminator yang tidak mendapatkan imbalan sukarela sama sekali dari peternak. Walaupun demikian inseminator tetap memberi pelayanan IB dengan memenuhi tanggung jawab bekerja secara profesional untuk menghasilkan hasil yang optimal.

\section{Faktor Internal dan Eksternal Inseminator Terhadap Keberhasilan Inseminasi Buatan (IB)}

Pengujian dilakukan dengan model analisis regresi berganda stepwiseyang digunakan untuk mengetahui besarnya pengaruh antara variabel independen yaitu masa kerja, intensitas pelatihan, tanggung jawab, ketelitian, dan kemampuan teknis manajemen straw dan deteksi birahi terhadap variabel dependen yaitu keberhasilan IB dengan nilai persamaan akhir dari hasil perhitungan regresi berganda di peroleh yaitu sebagai berikut.

$$
\mathrm{Y}=-6.307+0.671 \mathrm{X} 1+4.787 \mathrm{X} 2-0.479 \mathrm{X} 3+1.150 \mathrm{X} 4+0.888 \mathrm{X} 5
$$

Pada penelitian faktor internal diperoleh nilai $R$ Square sebesar 0.962 berarti $96.2 \%$ variabel keberhasilan IB (Y) dapat dijelaskan oleh variabel masa kerja (X1), intensitas pelatihan (X2), tanggung jawab (X3), ketelitian (X4), dan kemampuan teknis manajemen straw dan deteksi birahi (X5). Sedangkan sisanya $3.8 \%$ dapat dijelaskan oleh variabel-variabel lain yang tidak diteliti dalam penelitian ini.

\section{Uji Statistik F (Simultan)}

Pengujian ini dilakukan untuk melihat apakah semua variabel bebas yang dimasukkan dalam model mempunyai pengaruh secara bersama-sama terhadap variabel terikat. Hasil perolehan F-hitung pada kolom $\mathrm{F}$ yakni sebesar 40.620 dengan tingkat signifikansi = 0.000 , lebih besar dari nilai F-tabel yakni 3.59, dengan tingkat kesalahan $\alpha=5 \%$, atau dengan kata lain F-hitung $>$ F-tabel $(40.620>3.59)$ maka $\mathrm{H}_{0}$ ditolak.

Berdasarkan kriteria pengujian hipotesis jika Fhitung > F-tabel dan tingkat signifikansinya $(0.000<0.05)$, menunjukkan bahwa pengaruh variabel bebas (masa kerja, intensitas pelatihan, tanggung jawab, ketelitian, kemampuan teknis manajemen straw dan deteksi birahi) secara simultan berpengaruh terhadap variabel terikat (keberhasilan IB di Kabupaten Kerinci).

\section{Uji Statistik t (Parsial)}

Value (sig) lebih kecil dari pada 0,05 dalam nilai absolute pada taraf signifikan $\alpha=5 \%$ yaitu uji t parsial dalam analisi regresis berganda bertujuanuntuk 
mengetahui apakah variabel bebas (independen) secara pasrial (sendiri) berpengaruh signifikan terhadap variabel terikat (dependen) keberhasilan IB di Kabupaten Kerinci.

Variabel(X1) masa kerja yang membuktikan secara signifikan berpengaruh positif terhadap keberhasilan IB di Kabupaten Kerinci $(\mathrm{p}<0.05)$. Masa kerja petugas inseminator di Kabupaten Kerinci rata-rata berkisar 5-10 tahun membuktikan masuk dalam kategori cukup baik. Hasil penelitian ini sama dengan hasil penelitian Ardhani (2020) menyatakan bahwa rata-rata inseminator di Kecamatan Kota Bangun memiliki masa kerja $\geq 3$ tahun, yang mempengaruhi keberhasilan IB. Masa kerja tersebut dibutuhkan inseminator untuk peningkatan pengalaman dan pengembangan keterampilan dalam pelaksanaan IB. Artinya semakin lama masa kerja, akan semakin meningkatnya pengalaman inseminator menguasai bidang dalam memberi pelayanan IB yang menjadi tanggung jawabnya.

Variabel(X2) intensitas pelatihan membuktikan secara signifikan berpengaruh positif terhadap keberhasilan IB di Kabupaten Kerinci $(p<0.05)$. Frekuensi pelatihan diikuti inseminator mayoritas sebanyak 1 kali yakni pelatihan IB merupakan salah satu pelatihan yang paling penting dibutuhkan untuk inseminator agar dapat menginseminasi ternak. Keadaan ini membuktikan bahwa semakin banyak pelatihan yang diterima inseminator, maka inseminator akan mendapatkan pengetahuan, sikap dan keterampilan yang dibutuhkan dalam kegiatan pelaksanaan IB. Pelatihan mampu memberikan performan dan kemampuan kerja inseminator sesuai tuntutan perubahan zaman.

Perkembangan berbasis teknologi berpengaruh terhadap sistem pelatihan. Oleh karena itu, dengan adanya pelatihan dapat meningkatkan kemampuan inseminator tidak hanya dapat dilakukan secara konvensional, akan tetapi dapat dilakukan melalui pemanfaatan kemajuan teknologi. Melalui pelatihan, inseminator berinteraksi dengan instruktur pelatihan dan sesama inseminator guna memperoleh energi baru/motivasi, serta informasi terbaru lainnya yang diperlukan dalam pelaksanaan IB. Hal ini sesuai pendapat Anwas (2013) dalam penelitiannya menggungkapkan bahwa intensitas pelatihan berpengaruh signifikan terhadap kompetensi karena semakin sering dilakukan pelatihan, maka penyuluh/inseminator akan meningkatnya pengetahuan, sikap dan keahlian dalam pelaksanaan IB di lapangan.

Variabel (X3) tanggung jawab membuktikan secara signifikan tidak berpengaruh terhadap keberhasilan IB di Kabupaten Kerinci ( $p>0.05)$. Adapun yang di maksud tanggung jawab adalah kemampuan dan kualitas hasil pekerjaan inseminator yang mengarah pada terciptanya efisiensi dan efektivitas dalam pelaksanaan IB. Pada dasarnya setiap inseminator sudah memiliki rasa tanggung jawab tinggi dengan hasil penelitian sebesar $(51.02 \%)$.

Tanggung jawab yang tinggi berpengaruh terhadap beban kerja yang harus ditanggung inseminator dalam memberi pelayanan IB.Banyaknya beban kerja inseminator akan menyebabkan hasil yang dicapai menjadi kurang maksimal. Jika banyaknya pelaksanaan IB dalam sehari melebihi kapasitas inseminator, akibatnya tidak bisa melakukan pelaksanaan IB tepat waktu, apabila hal ini sering terjadi akan berdampak pada menurunnya potensi kinerja inseminator. Menurut Timpe (2000) menyatakan bahwa semakin tinggi tanggung jawab dimiliki seorang individu, maka akan mencapai produktivitas yang tinggi.

Variabel (X4) ketelitian membuktikan secara signifikan berpengaruh positif terhadap keberhasilan IB di Kabupaten Kerinci $(\mathrm{p}<0.05)$. Inseminator memiliki ketelitian yang baik dalam pelaksanaan IB dengan persentase $(55.72 \%)$ teliti.Hal ini sesuai dengan penelitian Elvinca (2018) bahwa sebagain besar inseminator di Kabupaten Tebo sudah teliti dan hati-hati dengan skor 4.20 kategori teliti.Semakin tinggi ketelitian inseminator, maka semakin tinggi pula tingkat keberhasilan IB. Sebaliknya, semakin rendah ketelitian, maka semakin rendah pula keberhasilan IB. Usaha yang perlu diperhatikan dalam menjaga ketelitian inseminator dengan mengoptimalkan kejelian dalam pelayanan IB, seperti tidak menunda pelayanan IB setelah pelaporan dari peternak. Jika keterlambatan pelayanan IB akan berakibat pada kerugian waktu yang cukup lama karena jarak antara birahi satu ke birahi selanjutnya membutuhkan waktu untuk peternak menunggu kira-kira 21 hari lagi.

Variabel (X5) kemampuan teknis manajemen straw dan deteksi birahi membuktikan secara signifikan berpengaruh positif terhadap keberhasilan IB di Kabupaten Kerinci $\quad(p<0.05)$. Semakin tinggi kemampuan teknis manajemen straw dan deteksi birahi, maka semakin meningkat keberhasilan IB. Inseminator di Kabupaten Kerinci memiliki kemampuan manajemen straw dan deteksi birahi kategori baik dengan persentase (43.57\%).

Pengetahuan berupa kemampuan teknis manajemen straw dan deteksi birahi harus dikuasai oleh seorang inseminator, karena hal itu merupakan landasan pokok dalam melaksanakan IB. Hal ini sesuai dengan Hastuti et al (2008) bahwa tingkat keberhasilan IB sangat dipengaruhi oleh faktor yang saling yang berhubungan seperti pemilihan sapi sebagai akseptor, kualitas semen, akurasi deteksi birahi peternak dan keterampilan inseminatordalam akurasi pengenalan birahi, sanitasi alat, penanganan dan pencairan kembali semen beku serta kemampuan melakukan inseminasi buatan (Herawati et al., 2012). 


\section{Faktor Eksternal Inseminator}

Pengujian dilakukan dengan model analisis regresi berganda stepwise yang digunakan untuk mengetahui besarnya pengaruh antara variabel independen yaitu jarak rumah dengan wilayah kerja, fasilitas pendukung, kondisi pos IB, sanitasi alat dan kelengkapan, imbalan sukarela terhadap variabel dependen yaitu keberhasilan IB dengan nilai persamaan akhir dari hasil perhitungan regresi berganda di peroleh yaitu sebagai berikut.

\section{$\mathrm{Y}=-50.211+0.565 \mathrm{X} 1+3.349 \mathrm{X} 2+1.144 \mathrm{X} 3+2.112 \mathrm{X} 4+0.000 \mathrm{X} 5$}

\section{Koefisen Determinasi (R2)}

$\begin{array}{lll}\text { Menurut Ajija (2011) uji koefisien determinas } \\ \text { (R2) atau } & \text { (R2 } & \text { adjusted). }\end{array}$ determinanmenunjukkan kemampuan garis regresi menerangkan variasi variabel terikat [proporsi (persen)] variasi variabel terikat yang dapat dijelaskan oleh variabel bebas. Pada penelitian faktor eksternal diperoleh nilai $R$ Square sebesar 0.892 berarti $89.2 \%$ variabel keberhasilan IB (Y) dapat dijelaskan oleh variabel jarak rumah dengan wilayah kerja (X1), fasilitas pendukung (X2),kondisi pos IB (X3), sanitasi alat dan kelengkapan (X4), dan imbalan sukarela (X5). Sedangkan sisanya $10.8 \%$ dapat dijelaskan oleh variabel-variabel lain yang tidak diteliti dalam penelitian ini.

\section{Uji Statistik F (Simultan)}

Pengujian ini dilakukan untuk melihat apakah semua variabel bebas yang dimasukkan dalam model mempunyai pengaruh secara bersama-sama terhadap variabel terikat. Hasil perolehan F-hitung pada kolom F yakni sebesar 13.239 dengan tingkat signifikansi = 0.001 , lebih besar dari nilai F-tabel yakni 3.59, dengan tingkat kesalahan $\alpha=5 \%$, atau dengan kata lain F-hitung $>$ F-tabel (13.239 > 3.59) maka $\mathrm{H}_{0}$ ditolak.Berdasarkan kriteria pengujian hipotesis jika F-hitung > F-tabel dan tingkat signifikansinya $(0.001<0.05)$, menunjukkan bahwa pengaruh variabel bebas (jarak rumah dengan wilayah kerja, fasilitas pendukung, kondisi pos IB, sanitasi alat dan kelengkapan, imbalan sukarela) secara simultan berpengaruh terhadap variabel terikat (keberhasilan IB di Kabupaten Kerinci.

\section{Uji Statistik t (Parsial)}

Value (sig) lebih kecil dari pada 0,05 dalam nilai absolute pada taraf signifikan $\alpha=5 \%$ yaitu $\mathrm{Uji} \mathrm{t}$ Parsialdalam analisis regresis berganda bertujuanuntuk mengetahui apakah variabel bebas (independen) secara pasrial (sendiri) berpengaruh signifikan terhadap variabel terikat (dependen) keberhasilan IB di Kabupaten Kerinci.

Variabel (X1) jarak rumah dengan wilayah kerja membuktikan secara signifikan berpengaruh posif terhadap keberhasilan IB di Kabupaten Kerinci $(\mathrm{p}<0.05)$. Berdasarkan hasil penelitian dan pengujian data diperoleh hasil bahwasanya jarak rumah inseminator dengan wilayah kerja berkisar 6-10 Km kategori dekat. Hal ini membuktikan bahwa semakin dekat jarak rumah inseminator dengan wilayah kerja, maka semakin tinggi keberhasilan IB. Jarak rumah yang dekat memudahkan inseminator melakukan penanganan ternak yang akan diinseminasi, apabila jarak rumah jauh dari wilayah kerja inseminator mengalami kendala seperti cuaca yang buruk dan kondisi jalan yang rusak, sehingga menyebabkan keterlambatan untuk menginseminasi ternak.

Variabel(X2) fasilitas pendukung membuktikan secara signifikan berpengaruh positif terhadap keberhasilan IB di Kabupaten Kerinci $(p<0.05)$. Berdasarkan hasil penelitian dan pengujian data diperoleh hasil bahwasanya kelengkapan fasilitas pendukung inseminator dengan persentase (80.61\%), semakin lengkap fasilitas pendukung, maka semakin tinggi tingkat keberhasilan IB. Fasilitas pendukung merupakan faktor penunjang inseminator memberi pelayanan IB seperti setiap inseminator harus memiliki sepeda motor yang berguna untuk mengjangkau lokasi akseptor berada pada lokasi yang cukup jauh.

Jika fasilitas pendukung tersebut tidak terpenuhi maka, akan berdampak pada kinerja inseminator yang rendah. Hal ini didukung dengan pendapat Ban dan Hawkins (1999) yang menyatakan bahwa ketidaktersediaan sarana penunjang untuk kegiatan penyuluhan menimbulkan masalah bagi seorang penyuluh yang kehilangan kepercayaan dari petani karena dianggap tidak mampu menyediakan sarana mereka butuhkan. Selanjutnya ditambahkan Hubeis (2007) persoalan keterbatasan fasilitas kerja merupakan salah satu faktor yang mempengaruhi etos kerja seorang pekerja.

Variabel(X3) kondisi pos IB membuktikan secara signifikan berpengaruh positif terhadap keberhasilan IB di Kabupaten Kerinci $(p<0.05)$. Pos IB di Kabupaten Kerinci sudah baik dalam segi pelayanan maupun ruang penyimpanan dengan persentase $(48.81 \%)$. Semakin bagus pelayanan maupun keadaan pos IB akan semakin menunjang tercapainya keberhasilan IB di Kabupaten Kerinci. Tersedianya sarana dan prasana pos IB, merupakan salah satu pendukung kelancaran pelaksanaan IB. Hal ini sejalan dengan pendapat Mosher (1987) yang menyatakan bahwa ketersediaan sarana dan prasarana penyuluh merupakan salah satu syarat kelancaran pembangunan pertanian. Ditambahkan Abdullah (2014) bahwa kualitas kerja menunjukkan sejauh mana mutu seorang pegawai dalam melaksanakan tugasnya meliputi kelengkapan, ketepatan, dan kerapian.

Variabel (X4) sanitasi alat dan kelengkapan membuktikan secara signifikan berpengaruh positif terhadap keberhasilan IB di Kabupaten Kerinci $(\mathrm{p}<0.05)$. Hasil penelitian dengan persentase (55.36\%) menunjukkan bahwa inseminator telah melakukan sanitasi alat dan kelengkapan dengan tepat dan benar. Semakin bagus/bersih kualitas sanitasi alat dan 
kelengkapan, maka akan semakin tinggi keberhasilan IB. Kebersihan alat dan kelengkapan IB sangat penting untuk mencegah kemungkinan berkembangnya bakteri/ jasad renik penyebab penyakit reproduksi ternak yang diinseminasi. Menurut Rauf (2013) menyatakan bahwa sanitasi berasal dari bahasa latin artinya sehat. Sanitasi adalah pemeliharaan/perawatan atau peningkatan kondisi-kondisi dan tingkat hygienes.

Variabel (X5) imbalan sukarela membuktikan secara signifikan tidak berpengaruh terhadap keberhasilan IB di Kabupaten Kerinci ( $p>0.05$ ). Imbalan sukarela yang diberikan peternak pada inseminator untuk mengawinkan ternak dengan kawin IB di daerah penelitian ini tidak terlalu tinggi. Rata-rata setiap peternak hanya mengeluarkan RP. 50.000. Jumlah biaya yang diberikan tidak terlalu besar terhadap keuntungan IB yang di dapat. Imbalan sukarela ini sebagai uang penganti bensin atau uang rokok untuk petugas inseminator.Namun inseminator tidak pernah membebankan biaya kepada peternak, karena pelayanan IB ini bersifat gratis.

Inseminator dalam memberikan layanan jasa inseminasi buatan kepada peternak harus dilakukan dengan pelayanan yang terbaik serta mengacu kepada Peraturan Perundangan yang berlaku. Sesuai dengan Peraturan Menteri Pertanian Nomor : 48/Permentan/PK.210/10/2A16 Tentang Upaya Khusus Percepatan Peningkatan Populasi Sapi dan Kerbau, dan terbitnya Peraturan Presiden Republik Indonesia Nomor : 87 Tahun 2016 Tentang Satuan Tugas Sapu Bersih Pungutan Liar (Saber Pungli) yang berdampak terhadap kekhawatiran petugas Inseminator dalam melaksanakan pelayanan pada masyarakat.

\section{SIMPULAN}

Penelitian tentang Analisis Keberhasilan Inseminasi Buatan (IB) Ternak sapi Berdasarkan Karakteristik Inseminator di Kabupaten Kerinci memiliki kesimpulan sebagai berikut:

1. Karakteristik internal inseminator yang berpengaruh terhadap keberhasilan IB di Kabupaten Kerinci adalah masa kerja, intensitas pelatihan, ketelitian, serta kemampuan teknis manajemen straw dan deteksi birahi, sedangkan tanggung jawab inseminator tidak berpengaruh nyata terhadap keberhasilan IB di Kabupaten Kerinci.

2. Karakteristik eksternal inseminator yang berpengaruh terhadap keberhasilan IB di Kabupaten Kerinci adalah jarak rumah dengan wilayah kerja, fasilitas pendukung, kondisi pos IB, serta sanitasi alat dan kelengkapan, sedangkan imbalan sukarela tidak berpengaruh nyata terhadap keberhasilan IB di Kabupaten Kerinci.

\section{Saran}

Untuk menunjang keberhasilan IB di Kabupaten Kerinci diharapkan perlu peningkatan kinerja inseminator pada pelaksanaan IB seperti melakukan pemeriksaan sesudah pelaksanaan IB yang bertujuan untuk mendeteksi status kebuntingan ternak sapi, serta mengetahui kondisi reproduksi sapi.

\section{DAFTAR PUSTAKA}

Abdullah, M.M. 2014. Manajemen dan Evaluasi Kinerja Karyawan. Penerbit Aswaja Pressindo. Yogyakarta.

Abidin, Z., Ondho, Y.S. dan Sutiyono, B. 2012. Penampilan berahi Sapi Jawa berdasarkan poel 1, poel 2, dan poel 3. Anim. Agric. J. 1(2): 86-92.

Al-Badry, K.I. 2012.Effect of various thawing times and temperatures on frozen semen quality of Friesian Bulls in Iraq.Int. J. Anim.Veter. Adv. 4: 384-388.

Anwas, O.M. 2013. Pengaruh pendidikan formal, pelatihan, dan intensitas pertemuan terhadap kompetensi penyuluh pertanian. Jurnal Pendidikan dan Kebudayaan, Vol. 19 (1): 50 - 62.

Ardhani, F., Lukman dan Firda Juita. 2020. Peran faktor peternak dan inseminator Terhadap keberhasilan inseminasi buatan pada sapi potong di Kecamatan Kota Bangun Jurnal Peternakan Lingkungan Tropis 3(1): 15-22.

Ban, A.W. dan Hawkins, H.S. 1999. Penyuluhan Pertanian. Kanisius. Yogyakarta.

Boothby, D. and Fahey, G. 1995. A practical guide artificial breeding of Cattle. East Melbourne (Australia): Agmedia. P. 127.

Bosker, J. 1997.Training Effectiveness, New York, Pergamon.

Chaikhun, T., T. Tharasanit, J. Rattanatep, F. Den Rensis, Techakumphu M. 2010. Fertility of swamp buffalo following the synchronization of ovulation by the sequential admi-nistration of GnRH and PGF2alpha combined with fixed-timed artifi-cial insemination. Theriogenology 74 (8): 1371-1376.

Elvica, N. 2018.Analisis Keberhasilan Inseminasi Buatan (IB) Berdasarkan Karaktersitik Inseminator Pada Ternak Sapi di Kabupaten Tebo.Tesis. Fakultas Peternakan Universitas Jambi.

Feradis. 2010. Bioteknologi Reproduksi pada Ternak. Afabeta. Bandung.

Hadi, P.U. dan N. Ilham. 2002. Problem dan prospek pengembangan usaha pembibitan sapi potong di Indonesia. Jurnal Litbang Pertanian 21(4): 148157.

Hastuti, D., Sudi Nurtini dan Rini Widiati 2008. Kajian Sosial Ekonomi Pelaksanaan Inseminasi Buatan Sapi Potong di Kabupaten Kebumen. Mediagro. Semarang.

Herawati, T., Anneke Anggraeni, Lisa Praharani, Dwi Utami dan Argi Argiris. 2012. Peran inseminator dalam keberhasilan inseminasi buatan pada sapi perah. Jurnal informatikapertanian 21(2): 81 - 88 . 
Hubeis, V.A. 2007. Motivasi, kepuasan kerja dan produktivitas penyuluhan pertanian lapangan kasus Kabupaten Sukabumi. Jurnal Penyuluhan September, Vol.3 (2): 91-99.

[Kementan] Kementerian Pertanian. 2017. Konsumsi Produk Peternakan Per Kapita Per Tahun, 20142016. Direktorat Jenderal Peternakan dan Kesehatan Hewan Kementerian Pertanian. Statistik Peternakan. Jakarta Agustus 2017. Hal.1216.

Kotur, B.R. dan S. Anbazhagan. 2014. Education and work experience influence on the performance. Journal ofBusiness and Management, 16(5): 23197668

Morrow, D.A. 1980. Current Therapy and Theriogenology Diagnosis, Treatment and Prevention of Reproductive Disease in Animals, WB Saunders Company, Philadelphia, USA.

Mosher, A.T. 1987. Mengerakkan dan Membangun Pertanian Syarat-Syarat Pokok Pembangunan Modernisasi. Terjemahan dari: Getting Agriculture Moving. Jakarta (ID): CV Yasaguna.

Rauf, Rusdin. 2013. Sanitasi Pangan dan HACCP. Yogyakarta. Graha Ilmu.

Roelofs, J., F. López-Gatius and R.H.F. Hunter, Van Eerdenburg FJCM, C.H. Hanzen. 2010. When is a cow in estrus clinical and practical aspects. Theriogenology. 74: 327- 44.

Saacke, R.G. 2008. Insemination factors related to timed AI in cattle. Theriogenology. 70: 479-484.

Saputra, A., Dihan Kurnia, Pajri Anwar. 2019. Performans reproduksi Sapi Bali di Kecamatan Sentajo Raya Kabupaten Kuantan Singingi. Journal of Animal Center, 1 (1): 1-10

Setiawan, D. 2018. Artificial Insemination of beef cattle UPSUS SIWAB program based on the calculation of non-return rate, service per conception and calving rate in the North Kayong Regency. The International Journal of Tropical Veterinaryand Biomedical Research. 3 (1): 7-11.

Setiyanti, S.W. 2012. Membangun kerja sama tim (kelompok). Jurnal STIE Semarang, VOL 4 (3): 60-65.

Siagian, Sondang P. 2009. Administrasi Pembangunan. Jakarta: Bumi Aksara.

Siregar, T.N. 2011. Teknologi manipulasi ovulasi secara imunologik untuk pelestarian sapi aceh dan peningkatan kesejateraan ekonomi peternak. Pidato Pengukuhan. Universitas Syiah Kuala Banda Aceh.

SNI. 2008. Semen Beku Bagian 1: Sapi. SNI 4869.1: 2008.

Susilawati, T. 2011. Spermatology. Universitas Brawijaya (UB) Press. Malang.

Tappa, B., R. Harahap, S. Said, R. Ridwan, H. Yanwa dan E. Sophion. 2012. Upaya Perbaikan Mutu Genetik Sapi Potong Dan Usaha Tani Hijauan
Makanan Ternak Di Kabupaten Belu, NTT. Pengembangan wilayah perbatasan NTT melalui penerapan teknologi.

Timpe, A.D. 2000. Seri Manajemen Sumber Daya Manusia. Produktivitas. PT. Gramedia.

Toelihere, M.R. 1985. Inseminasi Buatan Pada Ternak. Penerbit Angkasa. Bandung.

Toelihere, M.R. 1993. Inseminasi Buatan pada Ternak. Penerbit Angkasa, Bandung.

Utami, D. dan Angris, A. 2012. Peran Inseminator Dalam Keberhasilan Inseminasi Buatan Pada Sapi Perah. Bandung: Hasil Penelitian Balai InseminasiBuatan.

Utami, Tri. dan Tarsisius Considus Tophianon. 2014. Pengaruh suhu thawing pada kualitas spermatozoa sapi pejantan Friesian Holstein. Jurnal Sain Veteriner 32 (1): $0126-0421$

Wahyutae, H., R. Sutopo dan Y.S. Ondho. 2014. Pengaruh Jarak dan Waktu Tempuh Terhadap Post Thawing Motility, Abnormalis dan Spermatozoa Hidup Semen Beku. Skripsi Sarjana. Fakultas Peternakan dan Pertanian Universitas Dipenogoro, Semarang.

Watson, P.F. 1996. Cooling of Spermatozoa and Freezing Capacity.Reprod. Dom. Anim. 31:135140.

Yatim, W. 1982. Reproduksi dan Embriologi, Penerbit Tarsito, Bandung. 